\title{
MEMBEDAH TEORI SOSIOLOGI: Teori Pertukaran (Exchange Theory) George Caspar Homans
}

\author{
Wardani
}

\author{
Fakultas Ushuluddin dan Humaniora \\ IAIN Antasari Banjarmasin
}

Diterima tanggal 6 Januari 2016 / Disetujui tanggal 15 Maret 2016

\begin{abstract}
:
This article is aimed at analyzing critically George Caspar Homans's theory of exchange. The critical analysis that may be called here simply as "maping ideology" embodied in theory is needed to place the theory within the specific social and political condition, intellectual background, school of thought having great influence on it, and so forth, and also to assesses its limitedness as a theoretical frame-work of scientific research to explain complicated social phenomenon or human interaction. Influenced by psychological and economic theories, Homans's theory of exchange has been intended at the beginning by the author as attack against Marxism domination that addressed criticism to capitalism as macro-structure oppressing the proletariat by the ruling class and against Durkbeimian structural functionalism. By addressing the attack against Marxism and because of his intellectual and social background, Homans's theory then has been regarded as an explanation justifying the existing situation. Being attributed as psychological reductionism, as neglecting the important role of structure, and deterministic are some of the objections addressed to bis theory.
\end{abstract}

Kata kunci: Pertukaran Sosial, Stimulus-Respon, Ganjaran-Hukuman (Reward-Punishment)

\section{Pendahuluan}

Setiap teori sosiologis, bahkan setiap teori atau pemahaman apa pun, lahir dalam konteks yang tidak kosong dari moment kesejarahan, sosial, politik, atau pergumulan subjektif pencetusnya dengan pengalaman subjektifnya. Oleh karena itu, setiap teori sosiologi tentu saja memiliki segmen tertentu yang terbatas dalam menjelaskan fenomena sosial yang jauh lebih besar, bergerak dinamis, kompleks, dan bahkan kadang-kadang tak terprediksi. Dalam menjelaskan agama dan fenomena sosio-antropologis, beberapa teori yang dikaji oleh Daniel L. Pals, misalnya, dari teori E. B. Taylor dan James Prazer, Sigmund Freud, Émile Durkheim hingga Clifford Geertz tidak bisa menghindari sifat reduksionisnya, kekacauan teori, atau bias pengalaman penulis. ${ }^{1}$ Begitu juga, ada tiga paradigma, yaitu paradigma fakta sosial (social fact), paradigma definisi sosial (social definition), dan paradigma perilaku sosial (social behaviour), yang menjadi "payung" teori-teori sosiologis menunjukkan bahwa selalu ada ketidakpuasan terhadap suatu paradigma yang telah ada, hingga memunculkan ide yang ingin mengintegrasikannya dalam sosiologi berparadigma ganda (multiple paradigm) seperti digagas oleh George Ritzer dan beberapa sosiolog lain yang menganut linkage (paradigma integratif yang ingin menjembatani atau menghubungkan paradigma-paradigma yang tampak bertentangan).

Kompleksitas fenomena sosial adalah salah alasan penting mengapa suatu teori sosiologi tidak bisa menjelaskan atau menjadi conceptual frame-work (kerangka konseptual pemikiran yang dijadikan acuan) bagi peneliti dalam membingkai data. Meski memiliki keterbatasan, suatu teori sosiologi bisa menjelaskan suatu fenomena sosial secara tepat. Oleh karena itu, suatu teori harus ditempatkan pada objek kajiannya dan keunggulan-keterbatasannya. Untuk kepentingan menjelaskan anatomi teori sosiologi, digunakan skema analisis berikut:

1. Konteks sosial dan politik yang melatarbelakangi munculnya teori.

2. Realitas sosial yang mendasari teori.

3. Latar belakang sosial pencetus teori.

4. Aliran pemikiran yang mempengaruhi teori. 
5. Fenomena sosial yang ingin dijelaskan dan dipertanyakan yang bisa dipetakan dalam point berikut: (1) integrasi/ solidaritas sosial dan disintegrasi sosial/ konflik, (2) dominasi politik, ekonomi, atau kultural, (3) tindakan sosial yang rasional atau bermakna, (4) pertukaran sosial, atau (5) pilihan rasional.

6. Jenis penjelasan yang diberikan oleh teori yang bisa dipetakan kepada: (1) penjelasan genetik/ historis, (2) penjelasan fungsional, (3) penjelasan intensional dan rasional, (4) penjelasan kausal, atau (5) penjelasan deduktif/ induktif/ rasio/ logika.

7. Posisi teori dalam perdebatan body versus mind atau materi versus ide.

8. Posisi teori dalam perdebatan paradigma ilmu sosial dari segi: (1) jenis realitas (objektif versus subjektif atau empirik versus simbolik), (2) lingkup realitas (makro versus mikro).

9. Posisi teori dalam spektrum individualisme versus strukturalisme yang dilihat dari dua sisi: (1) voluntaristik versus deterministik versus linkage (integratif), (2) dualisme (maksudnya dikotomi antara individu dan struktur) versus dualitas (individu dan struktur dilihat sebagai dua hal yang tidak bertentangan).

10. Konsep yang dihasilkan dan proposisi teori yang dijelaskan atau dipahami.

11. Posisi teori dalam perdebatan metodologi penelitian dari segi: positivistik versus interpretatif.

12. Bias yang terkandung dalam teori, baik berupa bias nilai, kepentingan, atau kekuasaan.

13. Kritik terhadap konsep, teori, atau proposisi yang dihasilkan oleh teori.

Dengan skema analisis ini akan dijelaskan anatomi teori pertukaran (exchange theory) Homans, sehingga akan jelas kehandalan dan keterbatasannya dalam menjelaskan fenomena sosial.

\section{Anatomi Teori Pertukaran George Caspar Homans}

\section{Konteks Sosio-politik yang Melatarbelakangi Teori}

Setiap teori muncul dalam konteks sosio-politis tertentu. Teoritikus besar sosiologi, seperti Durkheim, Weber, dan Marx, merumuskan teorinya dalam konteks merebaknya industrialisasi di Eropa Barat pada abad ke-19. Marxisme muncul dari revolusi industri, khususnya tentang penderitaan kelompok buruh, yang kemudian membingkai perspektif Marx tentang konflik. Konflik yang dilihat Marx adalah antara kelompok buruh dan pemilik modal. Pemikiran Marxisme tampak berpengaruh hingga abad ke-20 di Barat, khususnya Amerika, ketika Homans hidup. Homans berada dalam situasi pengaruh kritik Marxisme terhadap kapitalisme yang mengglobal. Krisis ekonomi kemudian terjadi pada tahun 1930-an. Pada saat itulah, muncul karya Alvin Gouldner, The Coming Crisis of Western Sociology, yang menyerang Marxisme sebagai pemikiran yang mengutuk kapitalisme. Homans sebenarnya berada dalam konteks sosio-politis yang sama seperti yang dialami oleh Talcott Parsons. Teori konflik dalam menjelaskan masyarakat membangkitkan kegelisahan Parsons yang kemudian mengemukakan teori fungsionalisme struktural yang lebih menekankan pada keteraturan sosial. ${ }^{2}$ Parsons adalah kritikus penting Homans yang sama-sama berasal dari Harvard. Memang, ada kesamaan latar belakang pendidikan antara kedua sosiolog, yaitu keduanya memiliki pengetahuan tentang ilmu ekonomi. Parsons mengikuti program pascasarjana di School of Economics pada tahun 1924 di London sebelum ia berkenalan dengan Weber. Homans menimba pengetahuan tentang ekonominya di The Harvard Business School. ${ }^{3}$ Berbeda dengan Parsons yang-setelah berkenalan dengan Vilfredo Pareto, sosiologi Italia penggagas fungsionalisme struktural-konsisten mengembangkan teori itu, ${ }^{4}$ Homans yang meski mengenal pemikiran tokoh ini dan menulis tentangnya, An Introduction to Pareto: His Sociology, tidak mengembangkan teori fungsionalisme, kecuali hanya melalui teorinya tentang human group, kemudian ia segera meninggalkan teori ini. Perbedaan konteks yang dialami dan tokoh yang berpengaruh terkait dengan sikap keduanya terhadap serangan Marxisme terhadap kapitalisme dan kondisi ekonomi ketika itu. Dalam menyikapi kondisi yang ada, Parsons berupaya ingin mewujudkan komitmennya dalam membangun keseimbangan dan keteraturan sosial. Ia mempertanyakan bagaimana ketertiban dan keteraturan sosial yang menjamin tumbuhnya harmoni dalam masyarakat dapat diwujudkan? Jadi, krisis ekonomi, menurutnya, berkaitan dengan ketidakharmonisan dalam masyarakat akibat perbedaan kelas selalu dilihat dalam perspektif konflik.

2Muhammad Basrowi dan Soenyono, Teori Sosial dalam Tiga Paradigma (Surabaya: Yayasan Kampusina, 2004$), 151$.

${ }^{3}$ George Ritzer dan Douglas J. Goodman, Modern Sociological Theory, terjemah Alimandan (Jakarta: Kencana, 2005$), 362$.

${ }^{4}$ Zainuddin Maliki, Narasi Agung: Tiga Teori Sosial Hegemonike (Surabaya: Ipam, 2003), 98. 
Homans yang di samping akrab dengan teori ekonomi dan pernah mengikuti dinas militer angkatan laut pada Perang Dunia II yang melihat langsung pertarungan bangsa-bangsa, melihat perubahan kondisi ekonomi sebagai akibat logis dari pertukaran yang seimbang maupun tidak seimbang yang juga bisa dijelaskan dengan prinsip ekonomi dan psikologis, yaitu teori pertukaran. Inilah yang kemudian dijelaskan oleh Homans bahwa ada kaitan antara teori pertukaran dengan isu kekuasaan. Teori pertukaran mengenal dua hubungan: hubungan simetris (nilai yang dipertukarkan sama dan terjadi di antara orang yang secara sosial sama) dan hubungan a-simetris (tidak seimbang). Ketidakseimbangan tersebut disebabkan oleh sistem stratifikasi yang berkaitan dengan kekuasaan dan wewenang. Homans menjelaskan asal-mula kekuasaan dan wewenang dalam kaitannya dengan prinsip kepentingan mininum (principle of least interest): orang yang memiliki kepentingan yang paling sedikit untuk kelangsungan situasi sosial adalah yang paling bisa menentukan kondisi-kondisi asosiasi. Prinsip ini menghasilkan kekuasaan di tangan salah satu pihak yang berpartisipasi, "sebab dalam pertukaran seseorang memiliki kapasitas yang lebih besar untuk memberi orang lain ganjaran ketimbang yang mampu diberikan orang itu kepadanya" (Homans, 1974: 74). Jadi, kapitalisme yang mengglobal dan ketidakseimbangan antara kelas buruh dan pemilik modal, menurut Homans, adalah akibat logis dari pertukaran sosial yang tidak seimbang.

\section{Realitas Sosial yang Mendasari Teori}

Realitas yang mendasari teori pertukaran Homans adalah perkembangan pesat industri di Eropa, khususnya industri tekstil. Perkembangan pesat terjadi ketika diperkenalkannya industri tekstil yang digerakkan dengan mesin dalam industri tekstil di Inggris pada abad ke-18. Homans menganggap event ini adalah event yang sangat penting secara sosiologis, karena diperkenalkannya tekstil bertenaga mesin tersebut menjadi langkah awal bagi munculnya apa yang dikenal sebagai "revolusi Industri". Yang menjadi starting point (titik tolak) Homans adalah peningkatan dalam eksport kain cotton Inggris pada abad ke-18. Atas dasar realitas ini, Homans kemudian menulis:

[This] led to increased demand on the part of the industrial enterpreneurs for supplies of cotton thread, a demand that was not fully met by the existing labor force, spinning thread by hand on spinning wheels, so that the wages of spinners began to rise, threatening to raise the price of cloth and thus check the expansion of trade. ${ }^{6}$

(Ini menyebabkan permintaan yang meningkat kepada sebagian pengusaha industri untuk menyuplai benang kotton, suatu permintaan yang tidak sepenuhnya dapat dipenuhi dengan tenaga buruh yang ada, pemintalan benang dengan tangan dengan roda-roda pemintal, sehingga upah untuk para pemintal mulai muncul mengancam kenaikan harga pakaian dan karenanya dapat mengancam perluasan perdagangan).

Untuk mencegah kenaikan upah buruh, ongkos produksi, dan harga pakaian, serta kemunduran dalam perdagangan, para pengusaha di industri tekstil yang telah mengenal industri tekstil yang digerakkan dengan mesin pada industri-industri lain, mengembangkan mesin yang digerakkan dengan tenaga air atau uap air yang dapat memintal benang. Dengan didorong oleh keinginan mendapat keuntungan yang lebih banyak, banyak pengusaha mengembangkan mesin seperti itu dan mereka sukses.

Homans menganggap bahwa proses ini bisa direduksi ke sistem deduktif yang akan bisa menjelaskan mengapa para pengusaha tersebut mengambil sikap seperti itu. Sistem deduktif didasarkan atas prinsip psikologis sebagai berikut:

1. Manusia mungkin mengambil sikap yang menurut mereka dalam kondisi-kondisi tertentu mungkin akan menghasilkan keuntungan. (premis mayor)

2. Para pengusaha adalah manusia. (premis minor)

3. Sebagai pengusaha, mereka mungkin akan mendapatkan hasil dalam bentuk keuntungan yang meningkat. (kesimpulan) ${ }^{7}$

\footnotetext{
${ }^{5}$ Margaret M. Poloma, Contemporary Sociological Theory, terjemah tim Yasogama (Jakarta: Rajawali Pers, 2004$), 67$.

${ }^{6}$ George Ritzer, Contemporary Sociological Theory (New York: Alfred A. Knopf, 1988), 263.

${ }^{7}$ George Ritzer, Contemporary Sociological Theory, 263.
} 
Dengan bertolak dari asumsi dasar di atas, Homans menyatakan bahwa ia telah mampu menjelaskan tidak hanya perubahan sejarah (masuknya industri tekstil bertenaga masin di Inggris), melainka juga bisa menerangkan fenomena sosial atas dasar teori pertukaran yang prinsip-prinsipnya bersifat psikologis.

\section{Latar Belakang Sosial George Caspar Homans}

George Caspar Homans dilahirkan di Boston pada tanggal 11 Agustus 1910. Sebelum ke Harvard sebagai anggota "Society of Fellows" di mana ia kemudian menimba pengetahuan tentang sosiologi, Homans pernah mempelajari sastra Inggris dan Amerika pada tahun 1928-1934. Masa antara tahun 1934-1939 merupakan masa penting dalam keilmuannya di Harvard, di mana karir yang pernah dicapainya adalah sebagai ketua Department of Sociology (Jurusan Sosiologi). Homans juga pernah menjadi guru besar tamu (visiting professor) di Manchester. ${ }^{8}$

Kehidupan Homans ditulisnya dalam sebuah otobiografi, Coming to My Senses: the Authobiography of a Sociologist. Homans berkarir sebagai sosiolog setelah ia bertemu dengan psikolog dan ekonom, serta hidup sehari-hari dihadapkan dengan persoalan industri. Pada 1933, ia bergabung dengan Prof. Lawrence Henderson dan Elton Mayo di The Harvard Business School. Henderson adalah seorang ahli bio-kimia yang meneliti ciri-ciri psikologis dari pekerjaan industri. Sedangkan, Mayo adalah seorang psikolog yang meneliti faktor manusia dalam pekerjaan industri tersebut. Mayo kemudian menjadi direktur riset terkenal di the Hawtrhorne Plant of the Western Electric Company di Chicago. ${ }^{9}$

Homans terlibat langsung dalam kursus, membaca, dan diskusi yang dipimpin oleh Mayo. Mayo menyruh muridnya, ternmasuk Homans sendiri, untuk membaca karya antropolog sosial terkenal, yaitu Mallinowski, Redcliffe Brown, dan Firth, untuk memahami mengapa dalam masyarakat aborigin, upacara sosial-keagamaan dapat membantu produktivitas kerja.

Homans tertarik dengan karya antropologi tersebut dengan alasan berbeda. Penjelasan antropolog umumnya bertolak dari asumsi bahwa kultur yang dikajinya adalah unik, termasuk kultur masyarakat aborigin tersebut. Jadi, dengan asumsi ini, produktivitas kerja masyarakat besar kemungkinan berhubungan dengan kultur yang unik dan berbeda dengan kultur pada masyarakat lain. Homans mulai berpikir dan membantah asumsi antropolog ini dan teman-teman di kelompoknya, termasuk Clyde Kluckhohn. Alasannya adalah karena kultur serupa juga ditemukan dan berulang di tempat lain. Tidak mungkin bahwa kultur tersebut "dipinjamkan" di tempat lain. Asumsi Homans adalah bahwa semua manusia adalah sama. Jadi, kultur juga sama."

Ketika mengikuti dinas militer di angkatan laut pada Perang Dunia II, Homans kembali memikirkan asumsinya tersebut selama perjalanan di laut. Setelah perang, ia kembali ke Harvard yang ketika itu dipengaruhi oleh Talcott Parsons. Meski pernah memberikan kontribusi yang sangat berarti kepada fungsionalisme struktural dalam karyanya, The Human Group, namun Homans akhirnya meninggalkan teori itu, karena menurutnya skema konseptual hanya berguna sebagai titik tolak ilmu. Yang diperlukan selanjutnya adalah proposisi yang menghubungkan antar suatu konsep dengan konsep yang lain. Homans kemudian mengkritik Parsons dengan teori aksinya (action theory) yang dianggap hanya mampu mengemukakan skema konseptual, belum proposisi yang menghubungkan teori-teori. Proposisi yang digunakan Homans adalah proposisi psikologi perilaku yang dinyatakan oleh teman lamanya, B. F. Skinner. Dari sini, Homans menulis Social Behavior (1961) untuk menjelaskan mengapa, dalam kondisi apa, struktur sosial yang relatif abadi dapat muncul dari dan dipertahanakan oleh tindakan individual yang tak berkeinginan menciptakan struktur itu (tampak masih pengaruh fungsionalisme struktural pada Homan). Tapi, Homans menambahkan dengan proposisisnya bahwa setelah struktur terbentuk, yang berpengaruh selanjutnya adalah perilaku orang yang menjadi bagiannya atau berhubungan dengannya. Akhirnya, Homans sendiri menyatakan bahwa sosiologinya bercirikan individualitik, bukan kolektivitas. ${ }^{11}$

${ }^{8}$ http: www.kfunigraz. ac.at/502www/ogsoe/lexikon/klassiker/homans/23bio.htm.

${ }^{9}$ George Ritzer dan Douglas J. Goodman, Modern Sociological Theory, terjemah Alimandan (Jakarta: Kencana, 2005$), 362$.

${ }^{10}$ George Ritzer dan Douglas J. Goodman, Modern Sociological Theory, 363.

${ }^{11}$ George Ritzer dan Douglas J. Goodman, Modern Sociological Theory, 363. 


\section{Aliran Pemikiran yang Berpengaruh}

Teori pertukaran sosial George Homans dapat dipahami dari latar belakang aliran pemikiran yang mempengaruhinya:

1) Kritik terhadap fungsionalisme strukturtural Durkheimian

Fokus pandangan fungsionalisme bertumpu pada organisasi atau struktur sosial serta tujuan atau fungsi dari sistem yang besar atau kecil. Asumsi dasar fungsionalisme struktur adalah bahwa setiap struktur dalam sistem sosial adalah fungsional terhadap yang lain. Teori ini menekankan keteraturan (order) dan mengabaikan konflik dan perubahan dalam masyarakat. Konsep-konsep utamanya: fungsi, disfungsi, fungsi laten, fungsi manifest, dan keseimbangan (equilibrium). Menurut teori ini, masyarakat merupakan sistem sosial yang terdiri atas bagian-bagian yang saling berkaitan dan saling menyatu dalam keseimbangan. ${ }^{12}$ Teori ini sebenarnya berada dalam lingkup paradigma fakta sosial (social fact) yang mengasumsikan bahwa masyarakat seharusnya dikaji melalui fakta sosial yang terdiri dari dua tipe: struktur sosial (social structure) dan pranata sosial (social institution). ${ }^{13}$

Paradigma fakta sosial diambil dari dua karya Emile Durkheim: The Rules of Sociological Method (1895) dan Suicide (1897). Dua karya itu ditulis dari latarbelakang kritik Durkheim atas filsafat dan psikologi sebagai ancaman atas sosiologi yang belum berdiri sendiri. Ancaman filsafat muncul dari Auguste Comte dan Herbert Spencer. Menurut Durkheim, sosiologi harus bertolak dari hasil penelitian empiris, bukan teori-teori yang dihasilkan di belakang meja. Jika pemikiran Comte dan Spencer dilanjutkan, sosiologi akan menjadi filsafat. Untuk memisahkan sosiologi dari pengaruh filsafat supaya berdiri sendiri, sosiologi harus bertolak dari: fakta sosial (social facts). ${ }^{14}$

Dengan demikian, tekanan pada struktur yang berasal dari tradisi Durkheimian itu mencoba melihat sosiologi sebagai disiplin yang terpisah dari psikologi. Dengan ungkapan lain, fungsionalisme struktural adalah jenis sosiologi murni yang berbeda dari campuran sosiologi dan psikologi yang merupakan bagian penting dalam perkembangan sosiologi Amerika selama tahin 1920-an dan 1930-an. ${ }^{15}$

Meskipun sempat berkarir dan memberikan kontribusi teroritisnya, terutama melalui karyanya, The Human Group yang memperoleh dominasi teoritis pada tahun 1940-an, Homans akhirnya tetap memutuskan hubungannya dengan perspektif teoritis tersebut pada tahun 1950-an. ${ }^{16}$ Homans mengkritik pendekatan tersebut, termasuk kegagalannya "dalam menjelaskan berbagai hal". Apa yang dicoba oleh fungsionalisme ialaha mengklasifikasikan penelitian empiris (melalui pengembangan konsep-konsep yang tepat) dan mengembangkan proposisi-proposisi yang menguraikan konsep-konsep yang telah diklasifikan itu. Homans menyatakan bahwa fungsionalisme menyediakan "beberapa tingkat organisasi intelektual", tapi teori tersebut harus-harus melampaui usaha-usaha terbatas tersebut. Ilmu, menurut Homans, harus memuat dua hal, yaitu: menemukan dan menjelaskan. Dengan menemukan, kita menilai apakah itu benar-benar merupakan ilmu. Sedangkan, dengan menjelaskan, kita harus mengetahui sejauh ia berhasil sebagai suatu ilmu. Dengan demikian, fungsionalisme struktural merupakan usaha untuk menemukan dan menguraikan, tetapi gagal untuk mejelaskan. Di tahun 1950-an, Homans menyempurnakan teorinya tentang kelompok sosial (buman group) dalam tradisi fungsionalisme dengan tambahan-tambahan yang merupakan penjelasan struktur sosial melalui teori pertukaran sosial, ${ }^{17}$ suatu pergeseran ke sosiologi behavioral.

Kritik Homans terhadap paradigma fakta sosial, terutama ide Durkheim, dari tiga aspek:

\footnotetext{
${ }^{12}$ George Ritzer, Sociology: A Multiple-Paradigm Science, terjemah Alimandan dengan judul Sosiologi: Imu Pengetahuan Berparadigma Ganda (Jakarta: Rajawali Pers, 2004), 21.

${ }^{13}$ George Ritzer, Sociology, 18.

${ }^{14}$ George Ritzer, Sociology, 13.

${ }^{15}$ Margaret M. Poloma, Contemporary Sociological Theory, terjemah tim Yasogama, (Jakarta: Rajawali Pers, 2004$), 53$.

${ }^{16}$ Margaret M. Poloma, Contemporary Sociological Theory, 54.

${ }^{17}$ Margaret M. Poloma, Contemporary Sociological Theory, 58.
} 
1. Emergence, yaitu munculnya fenomena baru selama berlangsungnya interaksi. Konsep ini diterima oleh paradigma perilaku sosial, tapi sifat fenomena itu tidak perlu dijelaskan melalui proposisi baru lagi. ${ }^{18}$

2. Psikologi. Ketika Durkheim menyusun teorinya di abad ke-19, psikologi masih primitif dan masih berpengaruh terhadap sosiologi. Psikologi memusatkan perhatian pada tingkahlaku instingtif dan mengasumsikan bahwa sifat manusia sama secara universal. Sosiologi dewasa ini bukan lagi cabang dari psikologi. ${ }^{19}$

3. Metode Penjelasan. Menurut Durkheim, fakta sosial dapat diterangkan jika ditemukan fakta sosial lain yang menjadi penyebabnya. Meurut Homan, suatu fakta sosial memang bisa jadi penyebab fakta sosial lain. Tapi, ini belum merupakan penjelasan. Yang perlu dijelaskan adalah hubungan antara penyebab dan akibat dari hubungannya itu dari segi psikologi. Variabel psikologi bisa menjadi variabel perantara (intervening variables) di antara dua fakta sosial. ${ }^{20}$

Fakta sosial I-variabel psikologi—Fakta sosial II

(behavioral)

Homans juga mengkritik pranata dalam paradigma fakta sosial. Pranata dirumuskannya sebagai pola tingkahlaku sosial bersifat relatif tetap yang memelihara tingkah laku yang disepakati bersama oleh banyak orang. Dua di antara empat metode untuk menjelaskan pranata:

1) Penjelasan struktural: suatu pranata khusus tertentu muncul disebabkan karena ada hubungannya dengan pranata lain, belum berarti menerangkannya.

2) Penjelasan fungsional: pranata muncul karena masyarakat tidak dapat bertahan hidup atau tidak dapat bertahan dalam keseimbangannya tanpa pranata tersebut. ${ }^{21}$

Kritik Homans adalah sebagai berikut. Pertama, teori fungsional tidak menerangkan persoalan praktis, karena dari proposisinya tergambar konklusinya bahwa hidup matinya suatu masyarakat bukan bersangkut paut dengan eksistensi dari jenis pranata tersebut. Kedua, penjelasan psikologis (bahwa masyarakat tidak dapat bertahan hidup atau tidak dapat bertahan dalam keseimbangannya tanpa pranata) harus juga dilengkapi dengan analisis sejarah secara tepat bahwa semua pranata/ institusi adalah hasil perubahan yang bersifat historis. Sosiolog harus mampu menjelaskan fenomena perubahan sosial sekaligus perubahan yang bersifat psikologis. $^{22}$

2) Pengaruh sosiologi behavioral dalam teori pertukaran Homans

Sosiologi behavioral (behavioral sociology) muncul dalam konteks mengkritik pandangan Durkheimian tersebut dengan menerapkan prinsip psikologi ke dalam sosiologi. Fokus teori ini: hubungan antara akibat dari tingkah laku yang terjadi dalam lingkungan aktor dengan tingkah laku aktor. Akibat tingkah laku itu adalah variabel independen. Jadi, tingkah laku yang terjadi diterangkan melalui akibat-akibat yang mengikutinya kemudian.

Behavioral sociology juga mempersoalkan hubungan historis antara akibat tingkah laku yang terjadi dalam lingkungan aktor dengan tingkah laku yang terjadi sekarang. Konsep dasarnya: "reinforcement" (ganjaran, reward). Perulangan perilaku manusia dirumuskan dari efeknya terhadap perilaku itu sendiri. Sebaliknya, suatu ganjaran yang tak membawa pengaruh terhadap aktor tidak akan terulang. Contoh: makanan sebagai ganjaran bagi masyarakat; tapi bila seseorang tidak lapar, tidak ada perulangan. ${ }^{23}$

\section{Pengaruh Behaviorisme B.F. Skinner dan Teori Pilihan Rasional Ekonomi}

\footnotetext{
${ }^{18}$ George Ritzer, Sociology, 74-75.

${ }^{19}$ George Ritzer, Sociology, 75.

${ }^{20}$ George Ritzer, Sociolog, 75-76.

${ }^{21}$ George Ritzer, Sociology, 76-77.

${ }^{22}$ George Ritzer, Sociology, 77.

${ }^{23}$ George Ritzer, Sociology, 73.
} 
Teori pertukaran Homans sangat dipengaruhi oleh behaviorisme B. F. Skinner, pemuka exemplar paradigma perilaku sosial (social behavior). Sebagaimana diketahui, paradigma ini dipengaruhi oleh pendekatan behaviorisme dalam psikologi. Skinner berupaya menerapkan prinsip-prinsip psikologi aliran behaviorisme ke dalam sosiologi. Beberapa karyanya, seperti The Behavior of Organism: An Experimental Analysis?, Walden Two, dan Beyond Freedom and Dignity ditulis untuk menerapkan prinsip behaviorisme dalam sosiologi. ${ }^{24}$ Dalam Beyond Freedom and Dignity, Skinner menyerang paradigma definisi sosial secara langsung dan paradigma fakta sosial secara tidak langsung. Konsep kultur yang didefinisikan oleh paradigma fakta sosial dinilainya mengandung ide yang bersifat tradisional, khususnya mengenai nilai-nilai (social values). Menurut Skinner, pengertian kultur tidak perlu disertai unsur mistik, seperti ide dan nilai sosial. Alasannya adalah karena orang tidak dapat melihat secara nyata ide dan nilai dalam mengkaji masyarakat. Yang bisa dikaji adalah tingkah laku yang terpola (behavior of man and contingencies of reinforcement). ${ }^{25}$

Dalam Social Behavior: Its Elementary Forms (1961, 1974), Homans menyatakan bahwa teori pertukarannya berasal dari psikologi perilaku (behaviorisme) dan ilmu ekonomi dasar, khususnya teori pilihan rasional (rational choice). Homans (1984) sebenarnya menyesal menamakan teori dengan "teori pertukaran" karena ia melihatnya sebagai penerapan psikologi behavior pada situasi khusus. Homans membangun teorinya dengan mulai membahas paradigma perilaku sosial B. F. Skinner, khususnya tentang studi burung merpati Skinner:

Bayangkan seekor merpati segar atau naif berada dalam sangkarnya di laboratorium. Salah satu ciri perilaku bawaannya sejak lahir yang digunakannya untuk menyelidiki lingkungannya adalah paruhnya. Ketika merpati itu mematuk ke sana kemari di dalam sangkar, patukannya mengenai sebuah sasaran merah bundar, dan di saat itu psikolog yang menungguinya atau mungkin sebuah mesin otomatis memberinya makan dengan butiran padi. Faktanya adalah bahwa merpati itu mengulangi perilakunya kembali-kemungkinannya merpati itu tak hanya sekadar mematuk-matuk, tetapi mematuk sasaran merah bundar-akan meningkat. Dalam bahasa sederhana, dapat dikatakan bahwa merpati itu telah belajar mematuk target karena dengan perilaku demikian ia mendapat hadiah. ${ }^{26}$

Dari studi Skinner terhadap burung merpati, Homans kemudian memperhatikan perilaku manusia. Menurut Homans, merpati Skinner tidak terlibat dalam hubungan pertukaran yang sebenarnya dengan psikolog yang menelitinya. Berbeda dengan merpati itu, pada manusia pertukaran melihatkan dua pihak. Hubungan yang tidak timbal-balik pada studi itu disebutnya "perilaku individual" yang menjadi studi psikolog. Sedangkan, hubungan timbal-balik yang menjadi ciri "perilaku sosial" menjadi studi sosiologi. Menurut Homans, tidak diperlukan proposisi baru untuk menjelaskan perilaku individual dan sosial. Kemudian, dengan memperhatikan pertukaran sosial dalam mengangkat kasus di kantor menyusun Homans mengembangkan proposisi-proposisi. ${ }^{27}$

Teori pertukaran George Homans juga dipengaruhi oleh pandangan ekonomi seperti Adam Smith dan Ricardo yang bisa dirunut ke pemikiran filsafat John Stuart Mill. Adam Smith, misalnya, pernah mengemukakan ide memberi dan menerima antarbangsa dalam karyanya, An Inquiry into the Nature and Cause of the Wealth of Nations. Pada pertengahan abad ke-18, para pemikir sosial dengan serius berupaya menemukan bagaimana caranya memperhitungkan tatanan sosial di sekeliling mereka. ${ }^{28}$ Berdasarkan ide-ide mereka tersebut, dikembangkanlah asumsi-asumsi yang mendasari tingkah laku sosial:

1) Manusia pada dasarnya tidak mencari keuntungan maksimum, tetapi mereka senantiasa ingin mendapatkan keuntungan dari adanya interaksi yang mereka lakukan dengan manusia lain.

2) Manusia tidak bertindak secara rasional sepenuhnya, tetapi dalam setiap hubungan dengan manusia lain mereka senantiasa berpikir untung-rugi.

\footnotetext{
${ }^{24}$ George Ritzer, Sociology, 69.

${ }^{25}$ George Ritzer, Sociology, 70.

${ }^{26}$ George Ritzer dan Douglas J. Goodman, Modern Sociological Theory, 360.

${ }^{27}$ George Ritzer dan Douglas J. Goodman, Modern Sociological Theory, 361.
}

${ }^{28}$ Muhammad Basrowi dan Soenyono, Teori Sosial [Sosiologi?] dalam Tiga Paradigma, (Surabaya: Yayasan Kampusina, 2004), h. 202. Dalam kulit sampul depan tertulis "Teori Sosial", tapi dalam bagian dalam tertulis "Teori Sosiologi”. 
3) Manusia tidak memiliki informasi yang mencakup semua hal sebagai dasar untuk mengembangkan alternatif, tetapi mereka ini paling tidak memiliki informasi meski terbatas yang bisa untuk mengembangkan alternatif guna memperhitungkan untung rugi tersebut.

4) Manusia senantiasa berada pada serba keterbatasan, tetapi mereka ini tetap berkompetisi untuk mendapatkan keuntungan dalam transaksi dengan manusia lain.

5) Meski manusia senantiasa berusaha mendapatkan keuntungan dari hasil interaksi dengan manusia lain, tetapi mereka dibatasi oleh sumber-sumber yang tersedia.

6) Manusia berusaha memperoleh hasil dalam wujud material, tetapi mereka juga akan melibatkan dan menghasilkan sesuatu yang bersifat non-material, misalnya emosi, suka, dan sentimen. ${ }^{29}$

Basis teori ekonomi neo-klasik seperti tampak dalam asumsi-asumsinya ketika diterapkan ke tindakan sosial seperti diuraikan di atas berkaitan dengan teori pilihan rasional (rational choice). Di samping teori ekonomi neo-klasik, utilitarianisme dan teori permainan juga berpengaruh terhadap teori pilihan rasional yang model "kerangka" teorinya dikembangkan oleh Freiman dan Hechter. ${ }^{30}$ Menurut Ritzer dan Goodman, setidaknya teori pilihan rasional dalam bentuk awalnya yang belum sempurna yang mempengaruhi teori pertukaran. Dalam teori pertukaran, dijelaskan beberapa kompleksitas dalam teori pilihan rasional tersebut. ${ }^{31}$

\section{Fenomena Sosial yang Dijelaskan}

Dengan teori pertukaran (exchange), Homans ingin menjelaskan hubungan-hubungan sosial, minimal antara dua individu, atau antarkelompok. Pertukaran yang dimaksudkan oleh Homans adalah "pertukaran sosial" (social exchange) yang tidak hanya melibat materi, melainkan merupakan pertukaran non-materi yang lazimnya terjadi dalam sebuah hubungan sosial. Pertukaran sosial tentu saja mengambil bentuk dan dimensi yang berbeda dengan "pertukaran ekonomi” karena melibatkan emosi, namun menurut Homans tidak keluar dari prinsip dasar pertukaran dalam ekonomi yang asasnya adalah pilihan rasional.

Jadi, fenomena sosial yang dijelaskan adalah hubungan sosial (tindakan yang dilakukan individu yang diarahkan kepada orang lain) yang basisnya (unit analisisnya) adalah individu. Oleh karena itu, fenomena atau realitas sosial yang dijelaskan, dalam kategorisasi George Ritzer, adalah realitas sosial mikro-subjektif. Bukan struktur atau norma yang bekerja dalam hubungan sosial itu, melainkan pertimbangan stimulus-respon, atau reward and punishment.

\section{Jenis Penjelasan: Deduktif}

George C. Homans membangun teori pertukaran dengan proposisi-proposisinya dengan penjelasan deduktif untuk menjelaskan tatanan sosial (social order). Menurut Homans, kita hanya dapat menjelaskan tentang aspek-aspek tatanan dan perubahannya dengan mengacu pada beberapa proposisi umum. Hal itu merupakan bentuk spesifik dan runtut terhadap ide-ide dalam bentuk nalar deduktif (proposisi umum yang kemudian diterapkan pada kasus-kasus spesifik).

Di antara karya Homans adalah The Human Group dan Social Behavior: Its Elementary Forms. Buku yang pertama sebagian besar memuat bahasan tentang penelitian dalam relasi-relasi sosial. Sedangkan, yang kedua memuat lebih banyak teori dan proposisi-proposisi. ${ }^{32}$ Jadi, Social Behavior berisi pernyataan, statemen, atau proposisi umum untuk diterapkan dalam perilaku manusia (behavior). Dengan teori dan proposisi itu, perilaku individu dianalisis, atau individu sebagai satuan analisis.

Kaplan membedakan ada aspek utama dalam struktur internal teori. Ia menyebut suatu struktur "hirarkis" atau "deduktif" karena adanya hubungan antara eksplanan (perangkat pernyataan yang menjelaskan) dengan eksplanandum (pernyataan yang menggambarkan hal yang harus dijelaskan) sebagai struktur yang mendasari logika deduktif, seperti teori relativitas dalam fisika, teori genetika Mendelian, dan teori ekonomi Keynesian. Dalam sosiologi, apek kedua "dirangkai" atau "dipolakan" dengan yang pertama. Penjelasan

\footnotetext{
${ }^{29}$ Muhammad Basrowi dan Soenyono, Teori Sosial, 192-193.

${ }^{30}$ George Ritzer dan Douglas J. Goodman, Modern Sociological Theory, terjemah Alimandan, 357.

${ }^{31}$ George Ritzer dan Douglas J. Goodman, Modern Sociological Theory, 358.

${ }^{32}$ Muhammad Basrowi dan Soenyono, Teori Sosial, 206.
} 
deduktif, atau "hirarkis" menurut Kaplan, adalah "mencocokkan sesuatu ke dalam suatu pola yang memiliki kekuatan penjelasan dan, karenanya, kita bisa memperlihatkan sejauh mana yang sedang dijelaskan itu dapat disimpulkan dari pertimbangan yang lebih umum. ${ }^{33}$ Di samping itu, alur dibangunnya proposisi-proposisi tersebut juga berdasarkan "koherensi" antarproposisi. Proposisi sukses (success proposition), misalnya, tentang hubungan masa lalu dengan sekarang menyatakan bahwa semakin sering suatu tindakan diberi hadiah pada masa lalu, maka semakin besar kemungkinan tindakan itu akan dilakukan lagi. Proposisi ini koheren dengan proposisi nilai bahwa makin tinggi nilai hasil tindakan seseorang bagi dirinya, makin besar kemungkinan ia melakukan tindakan itu (hubungan nilai dengan tindakan), sehingga jika digabungkan, kita bisa menyimpulkan bahwa individu yang tak beruntung digambarkan membuat suatu tawaran untuk mengurangi beban dengan orang lain karena dengan itu ia menghindari ketidaksukaan. ${ }^{34}$

\section{Posisi teori: Body vs Mind; Materi vs Ide}

Sebagaimana dijelaskan oleh George C. Homans sendiri bahwa sosiologinya-meski tidak melihat individu terisolasi-tetap bercirikan individualistik, bukan kolektivistik. ${ }^{35}$ Teorinya tentang pertukaran sosial bertolak dari prinsip-prinsip penjelasan psikologis (psychological explanation), karena pandangannya bahwa manusia tidak bisa dijelaskan dengan pendekatan fungsionalisme struktur (bahwa struktural berupa institusi dan norma fungsional terhadap individu). Penjelasan tentang individu, menurutnya, harus bertolak dari asumsi yang melihat perilaku manusia sebagai manusia, the behavior of men as men. Penjelasan Homans tentang proposisinya adalah sebagai berikut:

They are propositions about the behavior of individual beings, rather than propositions about groups or societies as such; and the behavior of men, as men, is generally considered the province of psychology. ${ }^{36}$ (cetak miring dari Ritzer)

(Proposisi-proposisi itu lebih menerangkan fenomena perilaku individu daripada proposisi tentang kelompok atau masyarakat sebagaimana adanya, dan perilaku manusia sebagai manusia yang pada umumnya dianggap sebagai bidang kajian psikologi).

Penjelasan tentang manusia yang menjadi concern sosiologi tidak bisa dilakukan tanpa penjelasan hakikat atau sifat dasar (nature) manusia itu sendiri yang menjadi perhatian psikologi. Oleh karena itu, sosiologi Homans lebih menekankan faktor individu, atau individu sebagai unit analisis. Atas dasar ini, yang dipentingkan dalam teori pertukaran Homans adalah mind, bukan body, atau ide, bukan materi. Jadi, yang menjadi titik-tolak untuk mejelaskan hubungan sosial adalah kandungan kesadaran subjektif individu, bukan struktursosial seperti dalam paradigma fakta sosial.

Kutipan di atas menjadi alasan terpenting bagi George Ritzer untuk memasukkan pandangan Homans dalam paradigma perilaku sosial (social behavior). Berbeda dengan kalangan penganut definisi sosial yang menganggap individu adalah dinamis dan kreatif dalam proses interaksi, serta kebebasannya menginterpretasikan rangsangan dari luar dan bertindak atas dasar pendefinisiannya terhadap input-input, maka penganut paradigma perilaku sosial melihat individu dibatasi oleh sifat dasar stimulus. Pandangan inilah yang mendasari teori pertukaran Homans, yaitu lebih bersifat mikroskopik karena yang diperhatikan adalah relasi individu dan ganjaran (reinforcement, reward) yang berulang. ${ }^{37}$ Selain Ritzer, Brown dan Gimartin (1969) dalam publikasi hasil penelitian mereka di American Sociologist mempetakan tiga variabel dalam tiga paradigma, yaitu paradigma perilaku sosial yang variabelnya adalah individual, definisi sosial yang variabelnya dalah individual-group, dan fakta sosial yang variabelnya adalah group. ${ }^{38}$

\section{Posisi Teori dalam Perdebatan Paradigma:}

${ }^{33}$ Walter L. Wallace, The Logic of Science in Sociology, diterjemahkan Yasogama dengan judul Metoda Logika Ilmu Sosial, (Jakarta: Bumi Aksara, 1994), 80-82.

\footnotetext{
${ }^{34}$ Muhammad Basrowi dan Soenyono, Teori Sosial, 206-209.

${ }^{35}$ George Ritzer dan Douglas J. Goodman, Modern Sociological Theory, 363.

${ }^{36}$ George Ritzer, Sociology, revised edition, 157.

${ }^{37}$ George Ritzer, Sociology, revised edition, 145.

${ }^{38}$ George Ritzer, Sociology, edisi saduran, 95.
} 


\section{(a). Jenis Realitas: Objektif vs Subjektif; Empirik vs Simbolik}

Di samping kenyataan bahwa sosiologi Homans bertolak dari prinsip-prinsip psikologis yang menjadi individu sebagai unit analisis dan, karenanya berada dalam paradigma perilaku sosial, sebagaimana dijelaskan di atas, penekanan Homans pada realitas subjektif dan simbolik dapat dipahami dari kritiknya terhadap fakta sosial model Durkheimian tentang norma berikut:

Contoh terbesar fakta sosial adalah norma sosial dan norma kelompok yang pasti memaksakan kecocokan perilaku terhadap banyak orang. Persoalannya bukanlah keberadaan paksaan terhadap penjelasannya...Norma tidak secara otomatis memaksa; individu menyesuaikan diri, jika mereka berbuat demikian, karena mereka merasa mendapatkan keuntungan dengan menyesuaikan diri itu dan psikologilah yang menjelaskan pengaruh perilaku yang dianggap menguntungkan (Homans, 1967: 60). ${ }^{39}$

Kutipan di atas menunjukkan dua hal. Di satu sisi, ia setuju dengan Durkheim bahwa interaksi individu dengan norma menimbulkan sesuatu yang baru (penyesuaian diri). Di sisi lain, karena norma tersebut meski tampak memaksa banyak orang, tapi proses paksaan tersebut yang kemudian menimbulkan penyesuaian individu belum dijelaskan oleh sosiologi sebelum Homans. Proses penyesuaian itu, menurut Homans, harus dijelaskan dengan teori pertukaran, karena individu juga mendapatkan keuntungan (reward) dari penyesuaian diri itu. Kutipan ini menunjukkan "jejak-jejak" fungsionalisme yang masih belum seluruhnya hilang dari sosiologi Homans. Namun, dengan teori pertukaran itu, orisinalitas Homans adalah pada penjelasan psikologis proses tukar-menukar individu dan struktur itu. Akhirnya, yang ditekankan oleh Homans bukanlah struktur (pranata dan norma) itu lagi, melainkan respon subjektif individu. Jadi, teori Homans menjelaskan realitas subjektif, bukan realitas objektif, meskipun "subjektivitas" dalam pengertian sikap dinamis dan bebas dalam merespon stimulus, sebagaimana umumnya asumsi paradigma perilaku sosial, dibatasi oleh sifat dasar stimulus. Tapi, dalam proses memberikan respon itu (proses terjadinya stimulusrespon), teori pertukaran Homans tetap bertolak dari subject-centered (berpusat pada subjek) atau-meminjam istilah Anthony Giddens_- "perspektif emik". Karena sifatnya yang subjektif, realitas yang dijelaskan juga tidak bersifat empirik, melainkan bersifat simbolik, karena perilaku sosial sebagai pertukaran aktivitas tidak hanya bersifat nyata, material (uang, jasa, benda), melainkan juga tidak nyata, immaterial (perhatian, hubungan persahabatan, keakraban, permusuhan, kebencian) karena karakternya sebagai "social exchange" (pertukaran sosial). Oleh karena itu, hubungan reward-punishment atau stimulus-response adalah realitas simbolik yang memuat simbol-simbol yang harus didefinisikan.

\section{(b). Lingkup Realitas: Makro vs Mikro}

Karena subject-centered (berpusat pada subjek) dengan perangkat analisis psikologis terhadap individu, teori pertukaran George C. Homans terjebak pada penjelasan lingkup realitas mikro yang mengedepankan faktor subjektif atau individual. Dalam tabel berikut, Homans dikategorikan dalam paradigma mikro ekstrim:

\section{EKSTRIM}

\begin{tabular}{|l|}
\hline \multicolumn{1}{|c|}{ Makro } \\
\hline \multicolumn{1}{|l|}{ Parsons } \\
\hline Dahrendorf \\
\hline Blau \\
\hline White \\
\hline Boorman \\
\hline Breiger \\
\hline Duncan \\
\hline Mayhew \\
\hline
\end{tabular}

\section{Mikro}

\begin{tabular}{|l|}
\hline Blumer \\
\hline Homans's (exchange) \\
\hline Skinner \\
\hline Garfinkel \\
\hline Teoritisi rational choice \\
\hline Schnore \\
\hline \\
\hline
\end{tabular}


Ekstrimitas penjelasan realitas sosial pada level mikro Homans tampak pada klaimnya bahwa penjelasan sosiologis selama ini, seperti penjelasan fungsionalisme struktural yang diserangnya, adalah gagal dalam menjelaskan realitas sosial, karena dianggapnya tidak berbasis pada penjelasan perilaku manusia sebagai manusia, yaitu penjelasan psikologis. Padahal, realitas sosial yang begitu kompleks itu mengandaikan beragam penjelasan, atau beragam paradigma (ganda atau integratif) melalui linkage, baik yang mengintegrasikan makro dan mikro sebagaimana ditawarkan oleh Bailey (1994), Burt (1982), Fararo dan Skvoretz (1986), Hechter (1983), Hindes (1986), dan Smelser (1987) atau yang mengembangkan teori seperti George Ritzer (1979). ${ }^{40}$

Dalam perspektif yang dikemukakan oleh Theodore Abel terhadap tiga paradigma sosiologi, teori pertukaran George Homans adalah paradigma perilaku sosial yang perspektifnya adalah nominalisme sosial yang ekstrim, karena Homans mengatakan bahwa kelompok itu tidak lebih daripada perulangan kembali tingkahlaku/ perilaku individu. ${ }^{41}$

\section{Posisi Teori dalam Spektrum Individualisme vs Strukturalisme.}

\section{(a). Voluntaristik vs Deterministik vs Linkage}

Sebagaimana dikemukakan, teori pertukaran Homans berada dalam paradigma perilaku sosial, meskipun Homans sebelumnya berlatarbelakang secara intelektual dari tradisi fungsionalisme. Bagaimana hubungan individu dan struktur dalam perbandingan tiga paradigma dapat dikemukakan sebagai berikut.

Perbandingan tindakan individu menurut tiga paradigma: ${ }^{42}$

\begin{tabular}{|c|l|l||}
\hline \multirow{4}{*}{ Individu } & $\Rightarrow$ Fakta sosial & $\begin{array}{l}\text { Tindakan ditentukan oleh norma-norma, nilai-nilai } \\
\text { (pranata sosial), dan struktur social }\end{array}$ \\
\cline { 2 - 4 } & $\Rightarrow$ Definisi sosial & $\begin{array}{l}\text { Tindakan ditentukan oleh individu yang bebas } \\
\text { 'menginterpretasikan' stimulus dari luar }\end{array}$ \\
\cline { 2 - 4 } & $\Rightarrow$ Perilaku sosial & $\begin{array}{l}\text { Individu kurang bebas karena ditentukan sifat dasar } \\
\text { stimulus (tindakan mekanik) }\end{array}$ \\
\hline
\end{tabular}

Perdebatan antara Parsons dari eksponen paradigma definisi sosial dengan Homans tentang hubungan stimulus-respon bagi individu akan memperjelas posisi teori pertukaran Homans dalam spektrum individualisme vs strukturalisme yang voluntaristik atau deterministik. Parsons mengemukakan konsep voluntarism. Esensi dasar konsep ini adalah bahwa individu memiliki kemampuan untuk melakukan tindakan dalam pengertian menetapkan cara atau alat dari sejumlah alternatif yang tersedia dalam rangka mencapai tujuan. Individu (aktor, actor) menurut konsep voluntarisme adalah pelaku aktif dan kreatif serta mempunyai kemampuan menilai dan memilih dari alternatif tindakan. Meski sama-sama berpusat pada subjek (pada Parsons dikembangkan dengan metode interpretive understanding Weber), ${ }^{43}$ voluntarisme tersebut berimplikasi pada persoalan bagaimana individu merespon stimulus. Menurut voluntarisme, karena aktor adalah aktif, kreatif, evaluatif, individu bebas "menginterpretasikan" stimulus yang muncul. Itu artinya bahwa stimulus tidak secara deterministik menimbulkan respon tertentu yang dapat diprediksi. Begitu juga, keberlakuan atau munculnya respon sebagai akibat dari stimulus juga tidak bersifat deterministik, melainkan tergantung bagaimana ak.tor memaknai stimulus.

Berbeda dengan pandangan ini, Homans menganggap bahwa hubungan stimulus-respon lebih bersifat mekanis dalam pengertian bahwa stimulus selalu secara deterministik menimbulkan respon yang dapat diprediksi, atau "dijelaskan secara psikologis". Begitu juga, individu bukanlah aktor (dalam istilah paradigma definisi sosial) yang bebas, melainkan ditentukan karakter dasar stimulus yang muncul.

Determinisme dalam teori pertukaran Homans disebabkan juga oleh karena penjelasan psikologis itu dituangkannya dalam bentuk proposisi-proposisi (the more/ semakin..., more likely/ besar kemungkinan...) karenanya anggapannya bahwa selama ini sosiologi hanya menjelaskan konsep dan teori, belum proposisi yang

\footnotetext{
${ }^{40}$ Zainuddin Maliki, Narasi Agung, 240-242.

${ }^{41}$ George Ritzer, Sociology, edisi saduran, 96-97.

${ }^{42}$ Disarikan dari George Ritzer, Sociology, edisi saduran, 73.

${ }^{43}$ George Ritzer, Sociology, edisi saduran, 49.
} 
mampu menghubungkan antarkonsep. Proposisi-proposisi itu sendiri ditarik oleh Homans dari teori deterministik dalam ekonomi neo-klasik yang sebenarnya berlaku pada barang, benda fisik, tidak seperti manusia (lihat kritik-kritik terhadap Homans).

\section{(b). Dualisme vs Dualitas}

Persoalam dualisme atau dualitas bertolak dari persoalan hubungan antara struktur dengan individu (aktor atau agen). Setidaknya, ada pandangan sosiolog tentang struktur. Pertama, definisi yang sudah lazim tentang struktur model Durkheimian yang memandang struktur sebagai sesuatu yang berada di luar dan memaksa aktor. Kedua, definisi Anthony Giddens dalam teorinya tentang strukturasi. Menurut Giddens, struktur tidaklah berada "di luar" atau "eksternal" terhadap tindakan aktor. "Struktur adalah apa yang membentuk dan menentukan terhadap kehidupan sosial, tetapi bukan struktur itu sendiri yang membentuk dan menentukan kehidupan sosial itu" atau dengan istilah "generative rules and resources", tegas Giddens. Pandangan Durkheimian menganut dualisme struktur-aktor. Keduanya sebagai dua entitas yang terpisah. Sedangkan, Giddens menganut dualitas (dua hal yang tak terpisah) antara struktur-aktor, subjek-objek, struktur-proses, atau body and mind. ${ }^{44}$

Bagi Homans, struktur yang berada "di luar" atau "eksternal" itu tidak memaksa individu, tapi individu menyesuaikan diri dengan struktur melalui proses pertukaran. Beberapa kritik yang dilontarkannya terhadap penjelasan fungsionalisme struktural menunjukkan bahwa struktur, baginya, bukan unit analisis yang bisa menjelaskan kehidupan sosial. Penolakan itu memasukkan Homans ke wilayah mind, subjek, pada level mikro-subjektif. "Proses penyesuaian diri" Homans tidak sama dengan proses di mana individu-individu menentukan dan mempengaruhi stuktur (disebut sebagai struktur subjektif) dalam strukturasi Giddens, tapi proses "penyesuaian diri" itu segera "dibaca" oleh Homans sebagai proses stimulus-respon, exchange, sehingga unit analisisnya tetap individu. Jadi, Homans menganut pandangan dualisme struktur-individu (atau lebih tepatnya, agen). Keduanya dilihat sebagai dua kutub yang terpisah dan berlawanan. Perdebatan Homans dengan Parsons, tokoh utama fungsional struktural, dengan teorinay tentang aksi (action) menunjukkan dualisme struktur-individu dalam teori pertukaran Homans.

\section{Posisi dalam Perdebatan Metodologi Penelitian : Positivistik vs Interpretatif}

Istilah "positivisme" semula adalah istilah Auguste Comte untuk menyebut fase ketiga dalam teorinya tentang evolusi atau "hukum tiga tingkatan" yang ditandai dengan keyakinan terhadap sains. Positivisme semula diterapkan untuk menyebut asas keilmiahan "bard sciences" yang tolok-ukurnya: dapat diamati (observable), terukur (measurable), dan dapat diulangbuktikan (verifiable). Positivisme ingin menemukan teori-teori atau hukum-hukum melalui "keterulangan" (reguleritas) atau keajegan peristiwa-peristiwa fisika. Comte berobsesi agar sosiologi meniru positivisme hard sciences tersebut dengan mengembangkan "fisika sosial" atau yang pada tahun 1839 disebutnya sosiologi. Hasilnya adalah sosiologi positivistik yang, antara lain, mempengaruhi Durkheim. Menurut Jonathan Turner, positivisme sosiologi Comte menekankan bahwa "semesta sosial menerima perkembangan hukum-hukum abstrak yang dapat diuji melalui pengumpulan data yang hati-hati" dan "hukum abstrak itu dapat menunjukkan kenadungan mendasar dan umum dari semesta sosial, dan akan menspesifikasi 'relasi naturalnya"“. 45 Seperti yang tampak pengaruhnya pada Durkheim, exemplar paradigma fakta sosial, positivisme sosiologi menekankan objek kajiannya pada sesuatu yang dianggap empiris yang disebut "fakta sosial" (social fact) yang unit analisisnya adalah makro, baik makroobjektif (struktur) maupun makro-subjektif (norma). Tujuannya adalah untuk menemukan teori-teori atau hukum-hukum sosial yang universal, bukan keunikan-keunikan (partikularitas), atau pemahaman subjektif, seperti dalam perspektif emik Giddens, yang dianggap berdasarkan data empiris.

Istilah “interpretatif” lebih merujuk kepada pemahaman Weberian. Kesadaran subjektif dipahami melalui metode interpretive understanding atau verstehen Weber. Tujuannya bukanlah untuk menemukan teori-teori

${ }^{44} \mathrm{Ada}$ dua hal penting dalam teori strukturasi Giddens. Pertama, hubungan pelaku (agen) dan struktur merupakan dualitas; tindakan dan struktur saling mengandaikan. Kedua, sentralitas waktu (time) dan ruang (space), di mana ruang dan waktu bukan arena tindakan, melainkan unsur konstitutif dari tindakan dan perorganisasian masyarakat (Nur Syam, Bukan Dunia Berbeda: Sosiologi Komunitas Islam [Surabaya: Jenggala Pustaka Utama, 2004], h. 28-29. Zainuddin Maliki, Narasi Agung, h. 248; George Ritzer, Modern Sociological Theory, 510.

${ }^{45}$ George Ritzer, Modern Sociological Theory, 19-20. 
atau hukum-hukum yang universal, melainkan untuk memahami "tindakan yang penuh arti" dari individu, sebagaimana tampak dari teori voluntarisme Parsons. "Partikularitas" (keunikan-keunikan) dalam pengertian pendefinisian oleh individu terhadap tindakannya yang diarahkan kepada orang lain menjadi penting. Oleh karena itu, mencari teori atau hukum yang universal bukan tujuan perspektif interpretatif.

Teori pertukaran Homans merupakan suatu penjelasan yang asasnya positivistik. ${ }^{46}$ Pertama, dengan proposisi-proposisinya itu, Homans bermaksud untuk menjelaskan hubungan sosial yang "terbingkai" dalam teori yang sifatnya universal yang mampu menjelaskan kehidupan-kehidupan sosial. Oleh karena itu, ia tidak setuju dengan pandangan antropolog sosial, Mallinowski, bahwa produktivitas dalam masyarakat aborigin adalah karena faktor keunikan-keunikan dalam ritual sosial keagamaan mereka. Menurut Homans, semua kultur adalah sama. Oleh karena itu, produktivitas pada masyarakat aborigin itu dan masyarakat-masyarakat umum lain bisa dijelaskan dengan proposisi-proposisi yang sifatnya universal. Kedua, yang terpenting dan terkait dengan alasan pertama adalah "keterulangan" (reguleritas) peristiwa/ perilaku sosial setiap kali muncul faktor pemicunya, atau respon yang diprediksikan selalu muncul, meski dalam kultur dan individu yang berbeda, ketika stimulus ada. Ketiga, meski unit analisis dalam teori Homans adalah individu, tapi individu—tidak seperti dalam dalam paradigma definisi sosial yang melihat individu sebagai aktor bebas, aktif, kreatif, dan evaluatif dalam proses stimulus-respon-Homans melihat respon individu sangat ditentukan oleh karakter stimulus. Karakter penjelasan "mekanis" tersebut menjadikan individu "tunduk" di bawah hukum stimulusrespon, sehingga Homans tidak mempersoalkan bagaimana individu memaknai stimulus itu (ini adalah salah satu kelemahan teori Homans, karena bagaimana respon individu tidak hanya diterangkan secara mekanis itu, melainkan juga bagaimana individu memaknainya).

\section{Proposisi-proposisi}

Teori pertukaran (exchange) George Homans terletak pada proposisi-proposisi fundamentalnya. Ia mengkritik keadaan sosiologi sebelumnya yang hanya menghasilkan teori. Yang diperlukan sesungguhnya, menurut Homans, adalah proposisi-proposisi, karena suatu proposisi bisa menghubungkan suatu teori atau konsep dengan teori atau konsep lain. Proposisi-proposisi Homans adalah sebagai berikut:

\section{1) Proposisi sukses (The Success Proposition)}

For all actions taken by persons, the more often a particular action of a person is rewarded, the more likely the person is to perform that action (Homans, 1974: 16). ${ }^{47}$

(Untuk semua tindakan yang dilakukan seseorang, semakin sering tindakan khusus seseorang diberi hadiah, semakin besar kemungkinan orang melakukan tindakan itu [hubungan masa lalu—sekarang] ).

Ada beberapa hal yang ditetapkan oleh Homans mengenai proposisi sukses. Pertama, meski umumnya benar bahwa makin sering hadiah diterima menyebabkan makin sering tindakan dilakukan, namun pembahasan ini tak dapat berlangsung tanpa batas. Di saat tertentu individu benar-benar tak dapat bertindaka seperti itu sesering mungkin. Kedua, makin pendek jarak waktu antara perilaku dan hadiah, makin besar kemungkinan orang mengulangi perilaku. Sebaliknya, makin lama jarak waktu antara perilaku dan hadiah, makin kecil kemungkinan orang mengulangi perilaku. Ketiga, menurut Homans, pemberian hadiah secara intermiten lebih besar kemungkinanya menimbulkan perulangan perilaku ketimbang menimbulkan hadiah yang teratur. Hadiah yang teratur menimbulkan kebosanan dan kejenuhan. Sedangkan, hadiah yang diterima dalam jarak waktu tak teratur (seperti dalam perilaku perjudian) sangat mungkin menimbulkan perulangan perilaku. $^{48}$

\section{2) Proposisi Pendorong (The Stimulus Proposition)}

If in the past the occurrence of a particular stimulus, or set of stimuli, has been the occasion on which a person's action has been rewarded, then the more similar the present stimuli are to the past ones, the more likely the person is to perform the action, or some similar action (Homans, 1974: 23). ${ }^{49}$

\footnotetext{
${ }^{46}$ Lihat juga analisis Zainuddin Maliki, Narasi Agung, 239.

${ }^{47}$ Sebagaimana dikutip George Ritzer, Contemporary Sociological Theory, 266.

${ }^{48}$ George Ritzer dan Douglas J. Goodman, Modern Sociological Theory, 363-364.

${ }^{49}$ George Ritzer, Contemporary Sociological Theory, 266.
} 
(Bila dalam kejadian di masa lalu dorongan tertentu atau sekumpulan dorongan telah menyebabkan tindakan orang diberi hadiah, maka makin serupa dorongan kini dengan dorongan di masa lalu, makin besar kemungkinan orang melakukan tindakan serupa [frekuensi ganjaran—tanggapan/ tingkah laku sekarang] ).

Homans mengemukakan contoh yang sederhana: "Pemancing yang melemparkan kailnya ke dalam kolam yang keruh dan berhasil menangkap seekor ikan, akan lebih suka memancing di kolam yang keruh kembali". Homans tertarik pada proses generalisasi dalam arti kecenderungan memperluas perilaku keadaan yang serupa. Dalam contoh mengail, satu aspek generalisasi dapat mendorong dari mengail di kolam yang keruh ke mengail di kolam mana pun dengan derajat kerindangan tertentu. Begitu pula, keberhasilan menangkap ikan mungkin mendorong orang dari satu cara mengail ke cara mengail yang lain (sebagai contoh, dari mengail di sungai ke mengail di laut) atau mendorong orang dari mengail ke berburu. Tetapi, proses diskriminasi juga penting. Artinya, aktor mungkin hanya akan mengail dalam keadaan khusus yang terbukti sukses di masa lalu. Bila kondisi yang menghasilkan kesuksesan itu terjadi terlalu ruwet, maka kondisi serupa mungkin tidak akan menstimulasi perilaku. Bila stimuli krusial muncul terlalu lama sebelum perilaku diperlukan, maka stimuli itu benar-benar tak dapat merangsang perilaku. Aktor dapat menjadi terlalu sensitif terhadap stimuli, terutama jika stimuli itu sangat bernilai bagi aktor. Kenyataannya, aktor dapat menanggapi stimuli yang tak berkaitan, setidaknya hingga situasi diperbaiki melalui kegagalan berulang kali. Semuanya ini dipengaruhi oleh kewaspadaan atau derajat perhatian individu terhadap stimuli. ${ }^{50}$

3) Proposisi Nilai (The Value Proposition)

The more valuable to a person is the result of his action, the more likely he is to perform the action (Homans, 1974: $25)^{51}$

(Makin tinggi nilai hasil tindakan seseorang bagi dirinya, makin besar kemungkinan ia melakukan tindakan itu [hubungan nilai-tindakan] ).

Di kantor, misalnya, jika ganjaran yang diberikan seseorang kepada yang lain dianggap berharga, maka kemungkinan besar aktor akan melakukan tindakan yang dianggap bernilai tersebut dibanding dengan yang tak bernilai. Dalam point ini, Homans memperkenalkan konsep reward and punishment. Reward adalah tindakan-tindakan yang memiliki nilai positif; semakin bernilai ganjaran semakin besar kemungkinan tindakan akan dilakukan. Punishment adalah tindakan-tindakan yang memiliki nilai negatif; semakin mendapat hukuman suatu, maka aktor semakin tidak ingin melakukan tindakan. ${ }^{52}$

4) Proposisi Deprivasi-Kejemuan (The Deprivation-Satiation Proposition)

The more often in the recent past a person has recieved a particular reward, the less valuable any further unit of that reward becomes for him (Homans, $1974: 29){ }^{53}$

(Makin sering seseorang menerima hadiah khusus di masa lalu yang dekat, makin kurang bernilai baginya setiap unit hadiah berikutnya [hukum Gossen dalam ilmu ekonomi] ).

5) Proposisi Persetujuan-Agresi (The Aggression-Approval Proposition)

\section{Proposisi A :}

When a person's action does not recieve the reward he expected, or recieves punishment he did not expect, be will be angry; he becomes more likely to perform aggressive behavior, and the result of such behavior become more valuable to him (Homan, 1974 : 37). ${ }^{54}$

\footnotetext{
${ }^{50}$ George Ritzer dan Douglas J. Goodman, Modern Sociological Theory, 364.

${ }^{51}$ George Ritzer, Contemporary Sociological Theory, 267.

${ }^{52}$ George Ritzer, Contemporary Sociological Theory, 267.

${ }^{53}$ George Ritzer, Contemporary Sociological Theory, 267.

${ }^{54}$ George Ritzer, Contemporary Sociological Theory, 268.
} 
(Bila tindakan orang tak mendapatkan hadiah yang ia harapkan atau menerima hukuman yang tidak ia harapkan, ia akan marah; besar kemungkinan ia akan melakukan tindakan agresif dan akibat tindakan demikian menjadi makin bernilai baginya).

Dalam kasus di kantor, jika seseorang tidak mendapatkan nasehat yang ia harapkan, atau orang lain tidak mendapat pujian sebagaimana seharusnya, besar kemungkinan keduanya akan marah. Ini adalah konsep Homans tentang frustasi dan marah. Proposisi A merujuk kepada emosi negatif, sedangkan proposisi B berikut berkaitan dengan emosi positif. ${ }^{55}$

Proposisi B :

When a person's action recieves the reward he expected, especially a greater reward than he expected, or does not recieve punishment he expected, he will be pleased; he becomes more likely to perform approving behavior, and the results of such behavior become more valuable to bim (Homans, 1974 : 39). ${ }^{56}$

(Bila tindakan seseorang menerima hadiah yang ia harapkan, terutama hadiah yang lebih besar daripada yang ia harapkan, atau tidak menerima hukuman yang ia bayangkan, maka ia akan puas; ia makin besar kemungkinannya melaksanakan tindakan yang disetujui dan akibat tindakan seperti itu akan makin bernilai baginya).

Misalnya, di kantor, jika seseorang mendapat nasehat yang ia harapkan atau orang lain mendapatkan pujian, besar kemungkinan keduanya akan senang. Nasehat dan pujian adalah hal yang bernilai bagi keduanya. Proposisi persetujuan-agresi berhubungan dengan konsep keadilan distributif proses pertukaran. Yang dimaksud dengan keadilan distributif (distributive justice) adalah apakah ganjaran dan harga didistribusikan secara adil di antara individu yang terlibat? ${ }^{57}$

6) Proposisi Rasionalitas (The Rationality Proposition)

In choosing between alternative actions, a person will choose that one for which, as percieved by him at the time, the value, $V$, of the result, multiplied by the probability, $p$, of getting the result, is the greater (Homans, $1974: 43$ ). ${ }^{58}$

(Dalam memilih di antara berbagai tindakan alternatif, seseorang akan memilih satu di antaranya, yang dia anggap saat itu memiliki nilai (value, $V$ ), sebagai hasil, dikalikan dengan probabilitas ( $p$ ), untuk mendapatkan hasil yang lebih besar).

Dalam melakukan tindakan seperti itu, seseorang dikatakan memaksimalkan kegunaan (uitilitas) yang diharapkannya. Dalam kasus tindakan-tindakan yang berulang, proposisi rasionalitas menjelaskan bahwa jika rata-rata seseorang melakukan suatu tindakan disebut $\mathrm{A}$, maka dapat dirumuskan:

$$
\mathrm{A}=\mathrm{pV}
$$

Atau, Rata-rata (prediksi) = kemungkinan (probabilitas) keberhasilan x Nilai (value)

Contoh: seseorang dihadapkan pada suatu pilihan di antara dua tindakan. Yang pertama, jika sukses, akan membawanya kepada hasil yang, katakanlah, didasarkan atas pertimbangan 3 unit nilai baginya. Tapi, ia memperkirakan peluang untuk sukses/ berhasil hanya seperempat. Yang kedua akan membawa hasil yang pantas hanya dengan pertimbangan dua unit nilai. Tapi, ia memperkirakan peluang untuk sukses/ berhasil setengah. Atas dasar rasionalitas ini, karena $3 \times 1 / 4$ adalah lebih kecial daripada $2 \times 1 / 2$, maka proposisi rasional memprediksikan bahwa orang tersebut akan mengambil tindakan kedua. ${ }^{59}$

${ }^{55}$ George Ritzer, Contemporary Sociological Theory, 268.

${ }^{56}$ George Ritzer, Contemporary Sociological Theory, 268.

${ }^{57}$ George Ritzer, Sociology: A Multiple Paradigm Science (Boston: Allyn and Bacon, Inc., 1980), 163-164. George Ritzer menggunakan istilah “distributive justice" (keadilan distributif) dengan proposisinya: The more to a man's disadvantage the rule of distributive justice fails of realization, the more likely he is display the emotional behavior we call anger". Lihat juga dalam http; //www2. pfeiffer. edu/ Iridener/ courses/ GENPROP.HTML . Dalam saduran yang dilakukan oleh Alimandan dari karya Ritzer (80) tersebut proposisi itu disebut dengan "keadilan relatif" (relative justice).

${ }^{58}$ George C. Homans, Elementary Form of Social Behavior, 2nd edition, (New York: Harcourt Brace Jovanovich, 1974), sebagaimana dikutip dalam http; //www2. pfeiffer. edu/ Iridener/ courses/ GENPROP. HTML.

${ }^{59} \mathrm{http} ; / /$ www2.pfeiffer.edu/ Iridener/courses/GENPROP.HTML. 
Proposisi terdahulu sangat dipengaruhi behaviorisme. Sedangkan, proposisi rasionalitas ini sangat jelas dipengaruhi oleh teori pilihan rasional (rational choice). Menurut istilah ekonomi, aktor yang bertindak sesuai dengan proposisi rasionalitas adalah yang memaksimalkan kegunaannya (utilitas). ${ }^{60}$ Proposisi rasionalitas adalah upaya Homans menghubungkan proposisi kesuksesan, stimulus, dan nilai. Proposisi rasionalitas menerangkan kepada kita bahwa apakah orang akan melakukan tindakan atau tidak tergantung pada persepsi mereka mengenai peluang sukses. Tetapi, apa yang menentukan persepsi ini? Homans menyatakan bahwa persepsi mengenai apakah peluang sukses tinggi atau rendah ditentukan oleh kesuksesan di masa lalu dan kesamaan situasi kini dengan situasi kesuksesan masa lalu. Namun, proposisi rasionalitas tidak menjelaskan kepada kita mengapa seorang aktor menilai suatu hadiah tertentu lebih daripada hadiah yang lain. Menurut Homans, hal itu haruis dijelaskan dengan proposisi behavioristiknya. ${ }^{61}$

\section{Bias dalam Teori}

Teori Homans mengandung bias nilai. Ia begitu terlalu mementingkan dimensi psikologis sebagai sesuatu yang bernilai ketika seorang individu bertindak. Akibatnya, teorinya mengabaikan dimensi-dimensi lain dalam pertimbangan individu. Dengan ungkapan lain, Homans adalah seorang reduksionis psikologi, di mana penjelasan-penjelasan tentang hubungan sosial yang dikemukakan oleh beberapa pakar paradigma lain, seperti peran struktur bagi individu, "direduksi" oleh Homans ke penjelasan psikologis. Bias nilai dengan reduksi psikologi itu menyebabkan teorinya hanya menekankan satu sisi, yaitu dimensi subjektif. Di samping itu, teori Homans juga mengandung bias teoritik karena hanya menekankan sisi kepentingan rasional (rational choice dalam ekonomi) yang sesungguhnya hanya merupakan salah satu di antara beberapa pertimbangan. Bias kepentingan tampak karena dengan teori pertukaran yang asasnya teori atau hukum ekonomi secara tidak langsung Homans menjustifikasi keadaan yang sedang terjadi, yaitu kapitalisme yang merebak yang diserang Marxisme. Teori pertukaran membenarkan proses yang sedang terjadi, karena kapitalisme yang muncul seiring dengan industrialisasi adalah keadaan logis dan wajar. Kapitalisme adalah sebuah bentuk pertukaran yang tidak seimbang antara pemilik modal dan pekerja. Marx membacanya dengan konflik. Akan tetapi, bagi Homans, individu yang "menyesuaikan diri" dengan keadaan yang mengglobal itu mendapatkan keuntungan atau ganjaran, semisal penyediaan lapangan kerja. Hal ini hampir sama dengan kemiskinan yang-jika meminjam istilah kalangan fungsionalis_-adalah "fungsional" bagi kalangan tertentu, karena menyediakan tenaga kerja murah. Semua ini berlaku dalam teori pertukaran.

Bias kepentingan dimaksud sangat jelas dari latar belakang kehidupannya dan alasan ketertarikannya dengan sosiologi Pareto. Homans adalah seorang hartawan dari Boston. Ia pernah menganggur sebagai akibat depresi, tapi tentu saja tidak bangkrut. Pada musim gugur 1932, L.J. Henderson, seorang psikolog, menyelenggarakan seminar tentang teori Pareto. Homans diundang dan menjadi pemakalah. Homans menjelaskan teori sosiologi Amerika sangat konservatif dan anti-Marxis:

"Saya mengikuti Pareto karena ia menjelaskan kepada saya apa yang telah siap untuk saya yakini. Saya tak tahu semua alasan mengapa saya siap meyakini pikirannya, tetap dapat saya berikan satu alasan. Seorang telah berkata bahwa sosiologi modern merupakan suatu upaya untuk menjawab argumen revolusi. Sebagai seorang republikan Boston yang tak menolak keberadaan keluarga yang tergolong kaya, selama tiga puluhan tahunan saya merasa bahwa saya telah diserang secara pribadi, terutama dari Marxis. Saya siap menyakini Pareto karena ia memberikan saya pertahanan.” (Homans, 1962: 4) ${ }^{62}$

Kutipan di atas dengan sangat jelas menunjukkan kepentingan di balik pembelaannya terhadap Pareto, yaitu kepentingan sebagai kalangan kaya yang dengan teori pertukaran ingin memberikan pembenaran keadaan yang sedang terjadi, yaitu revolusi industri yang bagi kalangan Marxis menimbulkan masalah-masalah bagi kelompok proletar.

\section{Kritik Terhadap Teori Pertukaran Homans}

Teori pertukaran (exchange) George Homans dipengaruhi oleh karya B. F. Skinner. Homans mengkritik penjelasan pada level makro terhadap perilaku manusia sebagaimana Durkheim, Parsons, dan

\footnotetext{
${ }^{60}$ George Ritzer dan Douglas J. Goodman, Modern Sociological Theory, 366.

${ }^{61}$ George Ritzer dan Douglas J. Goodman, Modern Sociological Theory, 367.

${ }^{62}$ George Ritzer dan Douglas J. Goodman, Modern Sociological Theory, 84.
} 
Lévi-Strauss. Sebagai gantinya, ia berupaya menjelaskan perilaku sosial dalam term-term dasar psikologis, yaitu behaviorisme. Ia yakin bahwa prinsip psikologi behaviorisme dapat digunakan untuk menjelaskan tidak hanya perilaku individual, melainkan juga struktur sosial dan perubahan sosial. ${ }^{63}$

Lima proposisi George Homans karena berorientasi kepada perilaku individual dikritik oleh kalangan sosiolog penganut paradigma fakta sosial (social factist) karena mengabaikan struktur skala besar dan oleh kalangan sosiolog penganut paradigma definisi sosial (social definitionist) karena mengabaikan proses mental pada individu ketika terjadi pertukaran itu. Perdebatan antara Parsons dan Homans mewakili perdebatan antara penganut paradigma fakta sosial dan orientasi sosial behaviorisme. ${ }^{64}$

Ada dua keberatan yang dikemukakan oleh Parsons terhadap teori pertukaran Homans :

Pertama, Parsons mengkritik penjelasan Homans yang "melebur" perbedaan antara perilaku manusia dan perilaku binatang, di mana ia menarik analogi pertukaran sosial itu. Menurut Parsons, prinsipprinsip yang digunakan untuk menjelaskan perilaku manusia secara kualitatif berbeda dengan prinsip-prinsip yang digunakan untuk menjelaskan perilaku binatang. Parsons mengemukakan keberatannya terhadap penarikan prinsip-prinsip pertukaran oleh Homans dari studi Skinner terhadap burung merpati. ${ }^{65}$

Kedua, kritik Parson adalah bahwa "formulasi-formulasi paling umum yang diterapkan pada manusia sebagai manusia (yang akan saya sebut lebih tepat sebagai prinsip-prinsip aksi, dibanding prinsip-prinsip psikologis) tidak cukup untuk menjelaskan...sub-sistem-sub-sistem aksi yang kompleks". Dengan ungkapan lain, menurut Parsons, prinsip-prinsip psikologis tidak bisa menjelaskan fakta-fakta sosial. Homans gagal menunjukkan bahwa prinsip-prinsip psikologis dapat diterapkan pada level masyarakat. Sebagai dikatakan oleh Parsons, "Homans is under obligation to show how his principles can account for the principal structural features of large scale social systems". Akhirnya, Parsons berkesimpulan bahwa meskipun Homans harus melakukan ini, dia tetap akan gagal, karena fakta-fakta sosial adalah variabel-variabel yang bisa menjelaskan dan dijelaskan tanpa harus merujuk ke prinsip-prinsip psikologis Homans:

The alternative to this [Homans's] emphasis is to see acting units as part of organized systems, which have properties other than those attributable to...the...interaction between "men as men." They have languages, cultural values, legal systems, various kinds of institutional norms and generalized media. Concrete behavior is not a function simply of elementary properties, but of the kinds of systems, their various structures and the processes taking place within them. From this point of view, it is quite legitimate to be concerned with the organization of complex systems...long before their properties can be derived from elementary principles. ${ }^{60}$

Jika Parsons menganggap prinsip-prinsip psikologis Homans tidak bisa menjelaskan struktur sosial skala besar, Homans ternyata juga mengatakan bahwa Parsons juga belum bisa menjelaskan struktur sosial. Argumen kedua yang belum selesai itu, tegas Ritzer, setidaknya menunjukkan pertarungan antara paradigma fakta sosial dan perilaku sosial secara umum, atau antara fungsionalisme struktural dan teori pertukaran secara khusus. ${ }^{67}$

Di sisi lain, kritik-kritik terhadap Homans tergambar dengan jelas dari keberatan-keberatan kalangan sosiolog lain terhadap teori behaviorisme yang mendasari teori exchange Homans.

Simmel juga mengkritik teori pertukaran yang, menurutnya, dibangun atas dasar asumsi yang tautologis seakan-akan hubungan sosial selalu melibatkan hubungan pertukaran. ${ }^{68}$ Padahal, hubungan sosial

\footnotetext{
${ }^{63}$ George Ritzer, Contemporary Sociological Theory, 280.

${ }^{64}$ George Ritzer, Contemporary Sociological Theory, 280-281.

${ }^{65}$ George Ritzer, Contemporary Sociological Theory, 269.

${ }^{66}$ George Ritzer, Contemporary Sociological Theory, 269.

${ }^{67}$ George Ritzer, Contemporary Sociological Theory, 270.
}

${ }^{68}$ David Jary dan Julia Jary, The Harper Collins Dictionary of Sociology (New York: Harper Collins, 1991), h. 159; David G. Wagner, "Daring Modesty: on Metatheory, Observation, and Theory Growth", Steven Seiman dan David G. Wagner (eds.), Postmodernism and Social Theory (Cambridge: Basil Blackwell Ltd., 1992), 211 
adalah beragam, kompleks, dan banyak variabel yang tidak selalu bisa direduksi ke kepentingan atau alasan pertukaran.

Kritik lain terhadap Homans ditujukan kepada teorinya tentang kesadaran (consciousness). Homans dianggap gagal mengemukakan analisis yang cukup tentang kesadaran dalam proses pertukaran itu. Bengt Abrahamsson, misalnya, melihat Homans cenderung terfokus pada perilaku-perilaku yang tampak dan mengabaikan pengalaman-pengalaman dalam (inner experiences) aktor. Menurutnya, mengetahui pengalaman individual dan persepsi mereka terhadap ganjaran ketika melakukan tindakan-tindakan tertentu adalah sangat penting untuk memahami dan memprediksi perilaku mereka. Jack N. Mitchell juga mengkritik Homans dari sisi reduksionismenya dan kegagalannya untuk menjelaskan dinamika kesadaran itu. "Teori apa pun", tegas Mitchell, “yang berupaya menjelaskan atau 'masuk ke dalam' hakikat tindakan sosial manusia tidak bisa mengasumsikan secara eksplisit dan ketat bahwa interaksi yang dilakukan semata didasarkan atas rasionalitas kepentingan-kepentingan melalui proses biologis, psikologis, maupun ekonomis. Apa yang kurang adalah....pengertian tentang....adanya ketidakpastian, hal-hal rumit, dan negosiasi." ${ }^{9}$ Menurut Mitchell, kelemahan teori pertukaran Homans bisa diatasi dengan teori-teori yang dikembangkan oleh kalangan penganut paradigma definisi sosial, seperti Erving Goffman (dramaturgi) dan Harold Garfinkel (etnometodologi)..$^{70}$ Homans juga mengakui perlunya "mengembangkan psikologi lebih lengkap lagi". ${ }^{71}$

\section{Penutup}

Analisis terhadap teori pertukaran Homans dari berbagai segmennya dapat dijelaskan secara lebih sederhana dalam tabel berikut ini:

\begin{tabular}{|c|l|l||}
\hline No. & \multicolumn{1}{|c|}{ Skema Analisis Teori } & \multicolumn{1}{c|}{$\begin{array}{c}\text { Teori Pertukaran (Exchange) George C. } \\
\text { Homans }\end{array}$} \\
\hline \hline 1. & $\begin{array}{l}\text { Konteks sosio-politik yang } \\
\text { melatarbelakangi teori }\end{array}$ & $\begin{array}{l}\text {-Proses industrialisasi di Eropa Barat pada abad ke-19 } \\
\text { yang memunculkan Marxisme, khususnya tentang } \\
\text { penderitaan kelompok buruh. Konflik yang dilihat } \\
\text { Marx adalah antara kelompok buruh dan pemilik } \\
\text { modal. Homans berada dalam situasi pengaruh kritik } \\
\text { Marxisme terhadap kapitalisme yang mengglobal. } \\
\text {-Perang Dunia II yang berakibat pada perubahan } \\
\text { kondisi ekonomi. Ini mendorong Homans untuk } \\
\text { menjelaskan bahwa perubahan tersebut sebagai akibat } \\
\text { logis dari pertukaran yang seimbang maupun tidak } \\
\text { seimbang yang juga bisa dijelaskan dengan prinsip } \\
\text { ekonomi dan psikologis, yaitu teori pertukaran. Ada } \\
\text { kaitan antara teori pertukaran dengan isu kekuasaan. }\end{array}$ \\
\hline 2. & Realitas sosial yang mendasari teori & $\begin{array}{l}\text {-Upacara sosial keagamaan yang dapat membantu } \\
\text { produktivitas kerja pada masyarakat aborigin } \\
\text { (antropologi sosial). } \\
\text {-Keberulangan hal itu (karena ada pertukaran) } \\
\text { pranata sosial tidak hanya pada masyarakat aborigin, } \\
\text { tapi juga masyarakat modern (kritik Homans atas } \\
\text { antropologi sosial di atas yang melihat masyarakat } \\
\text { aborigin sebagai kultur yang unik). }\end{array}$ \\
\hline
\end{tabular}

${ }^{69}$ Keberatan seperti ini tidak hanya ditujukan kepada teori pertukaran Homans, melainkan juga kepada teori pilihan rasional (rational choice) yang mendasarinya. Tentang kritik-kritik penting terhadap teori ini, lihat Lawrence A. Young (ed.), Rational Choice Theory and Religion: Summary and Assessment (New York: Routledge, 1997).

${ }^{70}$ George Ritzer, Contemporary Sociological Theory, h. 275. Tentang kedua teori dimaksud lihat George Ritzer dan Douglas J. Goodman, Modern Sociological Theory, h. 322-332 (etnometodologi Garfinkel) dan h. 296-310 (dramaturgi Erving Goffman).

${ }^{71}$ George Ritzer dan Douglas J. Goodman, Modern Sociological Theory, 367. 


\begin{tabular}{|c|c|c|}
\hline 3. & Latar belakang sosial pencetus teori & $\begin{array}{l}\text {-Latar belakang ekonomi dan psikologi: } \\
\text { pertemuannya dengan Prof. Lawrence Henderson } \\
\text { (ahli bio-kimia) dan Elton Mayo (psikolog) di The } \\
\text { Harvard Business School. }\end{array}$ \\
\hline 4. & Aliran pemikiran yang berpengaruh & $\begin{array}{l}\text {-Behaviorisme B. F. Skinner } \\
\text {-Psiokologi behavioral } \\
\text {-Teori ekonomi neo-klasik (pilihan rasional) }\end{array}$ \\
\hline 5. & $\begin{array}{l}\text { Fenomena sosial yang dijelaskan/ } \\
\text { dipertanyakan }\end{array}$ & $\begin{array}{l}\text { "Pertukaran sosial" (social exchange), yaitu hubungan- } \\
\text { hubungan sosial, minimal antara dua individu, atau } \\
\text { antarkelompok yang tidak hanya melibat materi, } \\
\text { melainkan merupakan pertukaran non-materi yang } \\
\text { lazimnya terjadi dalam sebuah hubungan sosial. }\end{array}$ \\
\hline 6. & Jenis penjelasan & Penjelasan deduktif \\
\hline \multirow[t]{2}{*}{7.} & Posisi teori: & \\
\hline & Lody vs mind; materi vs ide & Mind; ide \\
\hline \multirow[t]{3}{*}{8} & $\begin{array}{l}\text { Posisi teori dalam perdebatan } \\
\text { paradigma: }\end{array}$ & \\
\hline & $\begin{array}{l}\text { LS Jenis realitas: objektif vs } \\
\text { subjektif; empirik vs simbolik }\end{array}$ & Subjektif; simbolik \\
\hline & $\begin{array}{l}\text { Les Lingkup realitas : makro vs } \\
\text { mikro }\end{array}$ & Mikro \\
\hline \multirow[t]{3}{*}{9.} & $\begin{array}{l}\text { Posisi teori dalam spektrum } \\
\text { individualisme vs strukturalisme }\end{array}$ & \\
\hline & $\begin{array}{l}\text { Voluntaristik vs Deterministik vs } \\
\text { Linkage }\end{array}$ & Deterministik \\
\hline & Es Dualisme vs Dualitas & Dualisme \\
\hline 10. & $\begin{array}{l}\text { Posisi dalam perdebatan metodologi } \\
\text { penelitian: Positivistik vs } \\
\text { Interpretatif }\end{array}$ & Positivistik \\
\hline 11. & Proposisi-proposisi & $\begin{array}{l}\text {-Proposisi sukses, pendorong, nilai, deprivasi- } \\
\text { kejemuan, persetujuan-agresi, rasionalitas }\end{array}$ \\
\hline 12. & $\begin{array}{l}\text { Bias dalam teori: nilai, teori disiplin } \\
\text { ilmu lain, kepentingan, dan } \\
\text { kekuasan }\end{array}$ & $\begin{array}{l}\text {-Bias nilai, yaitu reduksionisme psikologi, di mana } \\
\text { hubungan-hubungan sosial yang komplek, termasuk } \\
\text { peran struktur terhadap individu, direduksi ke } \\
\text { penjelasan psikologis. } \\
\text {-Bias teoritik, yaitu terlalu dipengaruhi oleh rational } \\
\text { choice dalam ekonomi. } \\
\text {-Bias kepentingan, yaitu menjustifikasi kepentingan } \\
\text { kalangan borjuis dalam revolusi industri dan } \\
\text { karenanya membela kapitalisme dari serangan } \\
\text { Marxisme. }\end{array}$ \\
\hline 13. & $\begin{array}{l}\text { Kelemahan (konsep, teori, atau } \\
\text { proposisi yang dihasilkan) }\end{array}$ & $\begin{array}{l}\text {-Kritik kalangan social factist teori Homans } \\
\text { mengabaikan peran struktur. } \\
\text {-Kalangan social definitionist. mengabaikan peran } \\
\text { mental individu tentang individu yang otonom dalam } \\
\text { memaknai hubungan sosialnya. } \\
\text {-Parsons: (1) menyamakan prilaku manusia dan } \\
\text { binatang dalam merespon tawaran yang menjadi dasar } \\
\text { analogi teorinya; (2) prinsip aksi tidak bisa } \\
\text { menjelaskan sub-sistem aksi yang kompleks. } \\
\text {-Simmel: adalah asumsi yang tautologis jika hubungan } \\
\text { sosial yang kompleks selalu harus dijelaskan dengan } \\
\text { pertukaran. }\end{array}$ \\
\hline
\end{tabular}




\begin{tabular}{|l|l|l|}
\hline \hline & -Bengt Abrahamsson: mengabaikan "pengalaman \\
& dalam" (inner experience) dalam kesadaran individu. \\
& -Jack N. Mitchell: kesadaran individu tidak kaku, \\
melainkan ada dinamika, tidak seperti dalam \\
pertukaran.
\end{tabular}

\section{DAFTAR PUSTAKA}

Basrowi, Muhammad dan Soenyono. Teori Sosial dalam Tiga Paradigma. Surabaya: Yayasan Kampusina, 2004.

Homans, George C. Elementary Form of Social Behavior. $2^{\text {nd }}$ edition. New York: Harcourt Brace Jovanovich, 1974, sebagaimana dikutip dalam http; //www2. pfeiffer. edu/ Iridener/ courses/ GENPROP. HTML.

Jary, David dan Julia Jary. The Harper Collins Dictionary of Sociology. New York: Harper Collins, 1991.

Maliki, Zainuddin. Narasi Agung: Tiga Teori Sosial Hegemonik. Surabaya: Ipam, 2003.

Nur Syam. Bukan Dunia Berbeda: Sosiologi Komunitas Islam. Surabaya: Jenggala Pustaka Utama, 2004.

Pals, Daniel L. Seven Theories of Religion. New York: Oxford University Press, 1996.

Poloma, Margaret M. Contemporary Sociological Theory, terjemah tim Yasogama. Jakarta: Rajawali Pers, 2004.

Ritzer, George Contemporary Sociological Theory. New York: Alfred A. Knopf, 1988.

. Sociology: A Multiple Paradigm Science (Boston: Allyn and Bacon, Inc., 1980.

. Sociology: A Multiple-Paradigm Science, terjemah Alimandan dengan judul Sosiologi: Ilmu Pengetahuan Berparadigma Ganda. Jakarta: Rajawali Pers, 2004.

Ritzer, George dan Douglas J. Goodman. Modern Sociological Theory, terjemah Alimandan. Jakarta: Kencana, 2005.

Wagner, David G. "Daring Modesty: on Metatheory, Observation, and Theory Growth", Steven Seiman dan David G. Wagner (eds.). Postmodernism and Social Theory. Cambridge: Basil Blackwell Ltd., 1992.

Wallace, Walter L. The Logic of Science in Sociology. Diterjemahkan Yasogama dengan judul Metoda Logika Ilmu Sosial. Jakarta: Bumi Aksara, 1994.

Young, Lawrence A. (ed.). Rational Choice Theory and Religion: Summary and Assessment (New York: Routledge, 1997.

http: www.kfunigraz. ac.at/502www/ogsoe/lexikon/klassiker/homans/23bio.htm.

http; //www2. pfeiffer. edu/ Iridener/ courses/ GENPROP.HTML. 